\title{
UV irradiation-promoting effect on the antibacterial activity of cyanobacterial extracts against plant pathogens: a first record
}

Munirah Aldayel ${ }^{1+}$ and Nermin El Semary ${ }^{1,2^{*}+}$ (D)

\begin{abstract}
Background: Cyanobacteria possess a wide array of bioactive compounds including those with antimicrobial activities. The target was to investigate the UV effect on antimicrobial activity of cyanobacterial extracts. Several cyanobacterial strains were isolated from Eastern region of KSA as well as three plant pathogenic bacterial strains. Four cyanobacterial strains were used. Two strains were isolated from Al Uquair region, Arabian Gulf, and identified as Synechococcus sp. and Oscillatoria sp. The two other strains were collected from brackish stream of underground water and were characterized as Synechocystis sp. and Phormidium sp. The antimicrobial bioassay was then performed using cyanobacterial aqueous extracts. The antimicrobial effect was estimated by measuring the inhibition zone compared to that of control. The extract was divided into 2 parts: part was not exposed to UV and the other was exposed to UV-B irradiation for $10 \mathrm{~min}$. The antimicrobial bioassay was performed for both parts of the extract, using plant pathogenic bacteria, namely, Erwinia sp., Pseudomonas sp., and Bacillus sp.

Main body: The antimicrobial profile was examined and results showed that the extracts showed nonantimicrobial effect before UV irradiation, and antimicrobial effect after UV exposure. Also, those that were active against pathogenic bacteria were more active after UV exposure. This is mostly attributed to a high optical energy of UV irradiation that subsequently had a significant impact on the electron transitions in the molecules of the extract rendering some of them more effective in their antibacterial action.
\end{abstract}

Conclusion: This short communication was the first report where the UV can alter the antimicrobial profile of cyanobacterial extracts. This is a novel approach in enhancing antibacterial activity. Future molecular investigations will be conducted to further characterize the isolate whose extract showed the highest response to UV treatment.

Keywords: Antimicrobial, Aqueous extract, Cyanobacteria, UV irradiation

\footnotetext{
* Correspondence: nelsemary@kfu.edu.sa

${ }^{\dagger}$ Munirah Aldayel and Nermin El Semary contributed equally to this work.

'Biological Sciences Department, College of Science, King Faisal University, Al Hofuf 31982, Kingdom of Saudi Arabia

${ }^{2}$ Botany and Microbiology Department, Faculty of Science, Helwan University, Ain Helwan, Cairo 11795, Egypt
}

\section{Springer Open}

(c) The Author(s). 2020 Open Access This article is licensed under a Creative Commons Attribution 4.0 International License, which permits use, sharing, adaptation, distribution and reproduction in any medium or format, as long as you give appropriate credit to the original author(s) and the source, provide a link to the Creative Commons licence, and indicate if changes were made. The images or other third party material in this article are included in the article's Creative Commons licence, unless indicated otherwise in a credit line to the material. If material is not included in the article's Creative Commons licence and your intended use is not permitted by statutory regulation or exceeds the permitted use, you will need to obtain permission directly from the copyright holder. To view a copy of this licence, visit http://creativecommons.org/licenses/by/4.0/. 


\section{Background}

$\mathrm{UV}$ is an electromagnetic radiation that is transmitted in waves of varying wavelengths and frequencies (Tsoulfanidis 1995). Ultraviolet radiation is mostly non-ionizing except for under certain conditions on some molecules (Kovács and Keresztes 2002). UV radiation can be divided into UV-

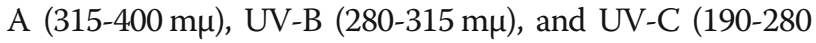
$\mathrm{m} \mu$ ) (Pattanaik et al. 2007). UV-A can cause lipid peroxidation, chlorophyll photo-bleaching, and inhibition of growth (Castenholz and Garcia-Pichel 2002). UV-B is also harmful but can be absorbed partly by ozone. It inhibits synthesis of chlorophyll a, nitrogen fixation, and ATP-synthase. UV-B also directly targets DNA causing dimerization between adjacent pyrimidine bases of DNA (Castenholz and GarciaPichel 2002). UV-C is strong but it does not reach the biosphere (Pattanaik et al. 2007). The effect of UV irradiation on cyanobacterial growth was studied (Babu et al. 1998). Nevertheless, there is still not much research on the effect of UV irradiation on the production of bioactive metabolites from cyanobacteria. In that regard, El Semary et al. (2015) demonstrated the significant effect of UV irradiation on cyanobacterial cells. UV treatment resulted in a drastic increase in the antimicrobial activity of cyanobacterial extracts. Nonetheless, the effect of UV on cyanobacterial extracts has never been studied, to the best of our knowledge. This is a novel approach in which the use of UV-B irradiation at a limited dose is tested for its ability to introduce positive change in the antimicrobial action of cyanobacterial extracts that have never been reported before. To investigate this, several extracts from marine and freshwater cyanobacterial strains were used against both gram-positive and gram-negative bacterial isolates from $\mathrm{Al}$ Ahsa Governorate, KSA.

This study aimed to study the effect of UV irradiation on strains from various habitats and nature.

\section{Material and methods \\ Cyanobacterial extracts}

Water samples were collected from marine (Al Uqair coast, Eastern Province, Al Ahsa, KSA) and freshwater habitats (canals fed from underground brackish water, Al Ahsa Governorate, KSA). Samples were examined by light microscopy, and cyanobacterial cells were isolated and cultured using F/2 for marine cyanobacteria (Guillard and Ryther 1962) and Bold's medium (Stein 1980) for brackish cyanobacteria. Cyanobacterial cultures were purified according to standard techniques and monospecific cultures were established. About $0.5 \mathrm{~g}$ of fresh biomass was ground in $5 \mathrm{ml}$ water and centrifuged where the extract was taken and condensed to $1 \mathrm{ml}$.

\section{Bacterial strains}

Three pathogenic bacterial strains were isolated according to standard microbiological techniques from local crops. The pathogenic bacterium, Erwinia sp., was isolated from infected pear whereas a pathogenic strain identified as Pseudomonas sp. was isolated from infected tomato (Gram-negative bacteria) as well as another strain, Bacillus sp. (Gram-positive bacteria).

\section{Antibacterial bioassay}

Sensitivity of pathogenic strains to the extracts was assessed by using the modified Kirby Bauer Disk Diffusion Susceptibility method (Bauer et al. 1966). Whatman No. 1 sterilized-paper disks were saturated with $30 \mu \mathrm{l}$ of extracts. Disks were dried and placed on the surface of the inoculated medium. The plates were then kept for $2 \mathrm{~h}$ at $4{ }^{\circ} \mathrm{C}$ to ensure the diffusion of the bioactive material, and then were incubated at $37^{\circ} \mathrm{C}$. Disks containing $30 \mu \mathrm{l}$ of water were left to evaporate and used as negative control.

\section{UV treatment}

The cabinet radiates UVB type $(280 \mathrm{~nm})$ and the sample located $25 \mathrm{~cm}$ from the UV lamp. The exposure continued for $10 \mathrm{~min}$. UVP device (California 91786).

\section{Results and discussion}

Four cyanobacterial isolates were purified and cultured. The isolates were identified using a light microscopy. Table 1 showed the phenotypic characteristics of those isolates which are from diverse habitats and exhibit morphological differences. With regard to antimicrobial bioassay, it was performed before and after exposure of cyanobacterial extracts to UV. Table 2 showed the antimicrobial profile from different cyanobacterial extracts before and after UV exposure. The extracts were ineffective against Pseudomonas sp. before UV exposure. However, they were effective as an antibacterial agent after exposure. Similarly, the extracts had no or little effect on the two other pathogenic bacteria. Nonetheless, they had potent antimicrobial activity after UV exposure. Negative control in all cases yielded a null $(0 \mathrm{~cm})$ inhibition zone.

Table 1 The cyanobacterial isolates used in the antimicrobial screening as sources of aqueous extract

\begin{tabular}{lll}
\hline Name & Habitat & Morphology \\
\hline Phormidium sp. & Brackish water & Unbranched filamentous, non-heterocystous \\
Synechocystis sp. & Brackish water & Coccoid unicellular \\
Synechococcus sp. & Marine & Coccoid unicellular \\
Oscillatoria sp. & Marine & Filamentous, non-heterocystous, unbranched \\
\hline
\end{tabular}


Table 2 The inhibition zone before and after UV exposure

\begin{tabular}{llll}
\hline Bacterial pathogen & Cyanobacterial extract & Inhibition zone before exposure & Inhibition zone after exposure \\
\hline Erwinia sp. & Phormidium sp. & $0.0 \pm 0.0$ & $1.1 \pm 0.1$ \\
& Synechocystis sp. & $0.9 \pm 0.1$ & $1.2 \pm 0.1$ \\
& Synechococcus sp. & $0.0 \pm 0.0$ & $0.9 \pm 0.1$ \\
Oscillatoria sp. & $0.0 \pm 0.0$ & $0.9 \pm 0.1$ \\
Pseudomonas sp. & Phormidium sp. & $0.0 \pm 0.0$ & $1.0 \pm 0.1$ \\
& Synechocystis sp. & $0.0 \pm 0.0$ & $1.0 \pm 0.1$ \\
& Synechococcus sp. & $0.0 \pm 0.0$ & $0.8 \pm 0.1$ \\
& Oscillatoria sp. & $0.0 \pm 0.0$ & $1.0 \pm 0.1$ \\
Bacillus sp. & Phormidium sp. & $0.0 \pm 0.0$ & $1.1 \pm 0.1$ \\
& Synechocystis sp. & $1.0 \pm 0.1$ & $1.5 \pm 0.1$ \\
& Synechococcus sp. & $0.0 \pm 0.0$ & $0.8 \pm 0.1$ \\
\hline
\end{tabular}

UV radiation has mutagenic and carcinogenic effects and although it is mostly non-ionizing, it probably causes photochemical changes. It causes damage of enzymes and cellular components as it causes oxidative stress via increasing reactive oxygen (Castenholz and Garcia-Pichel 2002). Cyanobacteria, however, developed several strategies to counteract the harmful effect of UV. Cyanobacteria overcome its effect by producing specific secondary metabolites such as myosporin-like amino acid (Holzinger and Lütz 2006) and scytonemin (El Semary and Khalif 2016). The antimicrobial effect of cyanobacterial extracts may be due to many reasons including cell membrane damage of pathogenic bacteria, protein damage, and oxidative damage by increasing reactive oxygen or by DNA interference (El Semary et al. 2015). Nonetheless, no reports are available on the effect of UV on cyanobacterial extracts. The interest in extracts stem from the need to induce chemical changes without mutagenizing the original source of extracts, i.e., cyanobacterial cells thereby establishing genetically modified organisms of unpredictable impact. It is highly likely that aqueous extracts have bioactive compounds that when receiving UV can be modified further and achieve a high antimicrobial impact on pathogenic bacteria. Nonetheless, the effect of UV on extracts had never been studied on cyanobacterial extract. However, Abd-Allah et al. (2018) used UV on extracts from Datura metel L. and the extracts were evaluated against 3 strains of pathogenic bacteria. They found that wavelength of 250-280 $\mathrm{nm}$ had high optical energy and subsequently had a significant impact on the electron transitions from $\left(\pi^{*}-n\right)$ and also $\left(\pi-\pi^{*}\right)$. The extracts were even more potent and had a great antimicrobial effect (Table 2). Similarly, it was found that the antimicrobial profile was changed and actually improved when extracts were exposed to UV.

From the aforementioned facts, the exposure in case of cyanobacterial cells to UV can be mutagenic and the extent of it can vary from one strain to another (Neelam and Rai 2003) as well as being highly unpredictable. Thereby, it was recommended to use cyanobacterial extracts instead as this approach will result in enhanced antimicrobial activity without mutagenically modifying the cyanobacterial cells with UV irradiation. The enhancing effect was on extracts for isolates of diverse morphology and nature. This only emphasizes the wide potential of that approach and its applicability on diverse strain types. Hence, further exploration/exploitation of this approach on different microorganisms with interesting attributes is recommended.

\section{Conclusion}

This is the first report, to the best of knowledge, about the change in antimicrobial profile of the cyanobacterial extracts using UV treatment. The exposure was for cyanobacterial extract not to the cells themselves. This is a novel application where the extracts themselves are modified without mutagenically altering the cyanobacteria, thereby causing less hazards and giving rapid enhancement in antibacterial activity.

\section{Abbreviation}

DNA: Deoxy ribonucleic acid; KSA: Kingdom of Saudi Arabia; UV: Ultraviolet

\section{Acknowledgements}

The authors would like to acknowledge the support of King Faisal University, Al Hofuf, Al Ahsa, KSA. Post code: 31982 for conduction of research.

Ethical approval and consent to participate

Not applicable (no human materials, data, or participants were involved).

Consent of publication

Not applicable

Authors' contributions

The two authors contributed equally to the manuscript. Professor N. El Semary was responsible for conception, work design, cyanobacterial isolation, and characterization as well as the writing up. Dr. M. Aldayel was responsible for bacterial isolation, characterization and antimicrobial bioassay, 
and supplying its data. They were both responsible for interpretation of data. Both authors have read and approved the manuscript.

\section{Funding}

The authors acknowledge the support and facilities provided by King Faisal University for the conduction of research.

\section{Availability of data and materials}

All data generated or analyzed during this study are included in this published article.

\section{Competing interests}

The authors declare that they have no competing interests.

Received: 6 July 2020 Accepted: 13 September 2020

Published online: 23 October 2020

\section{References}

Abd-Allah A, Mukhlif F, Al-Shaheen Y, Al-Shaheen M (2018) The effect of UV irradiation on antimicrobial activity of water extract from Datura metel L. IOP Conference Series: Materials Science and. Engineering. 454:012109 10.1088/ 1757-899X/454/1/012109. https://iopscience.iop.org/article/10.1088/1757899X/454/1/012109/meta

Babu GS, Joshi PC, Viswanathan PN (1998) UVB-induced reduction in biomass and overall productivity of cyanobacteria. Biochem Biophys Res Commun 244:138-142

Bauer AW, Kirby WM, Sherris JC, Turck M (1966) Antibiotic susceptibility testing by a standardized single disk method. Amer J Clin Pathol 45:493-496

Castenholz RW, Garcia-Pichel F (2002) Cyanobacterial responses to UV-radiation. In: Whitton BA, Potts M (eds) The ecology of cyanobacteria: their diversity in time and space. Kluwer Academic Publishers Dordrecht, the Netherlands, pp 591-611

El Semary NA, Khalif A (2016) Cyanobacteria dominating palm trees' beds at AlAhsa Oasis and possession of scytonemin pigment: first record. Egy J Agric Res Special volume:108-114

El Semary NA, Osman ME, Ahmed AS, Botros HW, Farag AT (2015) Antibiosis towards human and plant pathogens via radiation-induced Synechococcus elongatus. Egypt J Biol Pest Control 25(2):393-399 Accessed from https:// search.proquest.com/openview/0d5f0cc198c27a15d20f91cd56cbd5d2/1?pqorigsite $=$ gscholar \&cbl $=886351$

Guillard RRL, Ryther JH (1962) Studies of marine planktonic diatoms. I. Cyclotella nana Hustedt and Detonulaconfervaceae (Cleve) Gran. Can J Microbiol 8: 229-239

Holzinger A, Lütz C (2006) Algae and UV irradiation: effect on ultrastructure and related metabolic functions. Micron 37:190-207

Kovács E, Keresztes Á (2002) Effect of gamma and UV-B/C radiation on plant cells. Micron 33:199-210

Neelam A, Rai LC (2003) Differential responses of three cyanobacteria to UV-B and Cd. J Microbiol Biotechnol 13(4):544-555 Accessed from https://www. researchgate.net/publication/258206294_Differential_responses_of_three_ cyanobacteria_to_UV-B_and_Cd

Pattanaik B, Schumann R, Karsten U (2007) Effects of ultraviolet radiation on cyanobacteria and their protective mechanisms. In: Seckbach J (ed) Algae and cyanobacteria in extreme environments. Series: Cellular origin life in extreme habitats and astrobiology. Springer, Berlin, p 31

Stein J (1980) Handbook of phycological methods. Culture methods and growth measurements. Cambridge University Press, p 448

Tsoulfanidis N (1995) Measurement and detection of radiation, 2nd edn. Taylor \& Francis, New York, p 1

\section{Publisher's Note}

Springer Nature remains neutral with regard to jurisdictional claims in published maps and institutional affiliations.

\section{Submit your manuscript to a SpringerOpen ${ }^{\circ}$ journal and benefit from:}

- Convenient online submission

- Rigorous peer review

- Open access: articles freely available online

- High visibility within the field

- Retaining the copyright to your article

Submit your next manuscript at $\boldsymbol{\nabla}$ springeropen.com 